\title{
The importance of positive messages and solution-oriented framing of climate change: A case- study in the context of secondary school education.
}

\author{
Mag. Maximilian Riede \\ Institut für Geographie \\ Universität Innsbruck \\ alpS - Zentrum für Klimawandelanpassung \\ Ass.-Prof. Dr. Lars Keller \\ Institut für Geographie \\ Universität Innsbruck \\ alpS - Zentrum für Klimawandelanpassung \\ Maga Anna Greissing \\ Institut für Geographie \\ alpS - Zentrum für Klimawandelanpassung \\ Universität Innsbruck
}

\section{Introduction}

This paper presents a case-study of an educational intervention that has been developed for introducing climate change and energy issues into secondary school education and for evaluating them in terms of effectiveness. Some reasons for its importance are briefly given hereafter.

There is plenty of scientific proof to state that climate change is not merely a natural phenomenon, but has also been and continues to be influenced by human induced greenhouse gas emissions (Hegerl et al. 2007; Salomon et al. 2007; IPCC 2013). In order to cope with climate change challenges, it has thus become increasingly important to find technological innovations, to implement carbon 
taxes or legal regulations, and, above all, to change the mind-set of individuals to facilitate pro-environmental behaviour. As a result, climate change is no longer a topic of science only, but has started to enter the realms of public discussion and individual lifestyle choices.

In addition to climate change mitigation measures, adaptation strategies play a central role for keeping the balance of fragile human-environment systems and for developing the necessary conditions for transition systems (Cosbey et al. 2007; Allison et al. 2009). In this process, the development and expansion of renewable resources will be as important as the responsible and efficient use of resources by the individual. However, only the raising of awareness for environmental problems connected to climate change is likely to lead to both a better acceptance of top-down measures (such as new directives and laws for environmental protection), and a behavioural change and voluntary engagement of people on a personal level. Mitigation measures tending to reduce mankind's ecological footprint thus have to target the increase of awareness not only for the phenomenon of global climate change and its consequences, but also, and most importantly, on how every person can make a difference. Young people are the societal group in this process as they are not only the decision makers of tomorrow, but will also and much longer than any generation before be affected by climate change and energy-related challenges. This new generation is asked to adapt its own behaviour as well as society as a whole to the new conditions. It is thus imperative for the future to include young people more intensively into debates on climate change, renewable resources, and energy efficiency, and to strengthen not only their awareness for climate change and energy-related challenges, but also their capacities for action on the ground.

Children's and teenagers' actual 'use' of energy and their potential to reduce it has not yet been examined comprehensively enough in order to determine whether a change in their behaviour has a similar environmental impact as that of an adult's. However, different studies indicate that, increasing with age, children and adolescents can also actively influence their parents' values, attitudes and decisions (Ballantyne et al. 1998). It has also been stated that environmental interventions induced by children can result in spill-over effects on their families (Hiramatsu et al. 2014).

Barbara Hinger (Hg.), Zweite „Tagung der Fachdidaktik“ 2015.

Sprachsensibler Sach-Fach-Unterricht - Sprachen im Sprachunterricht.

(C) 2016 innsbruck university press, ISBN 978-3-903122-51-2, DOI 10.15203/3122-51-2 
It is evident that in addition to the family and the social environment, formal education plays a major role for the development of the mind-set of teenagers and their construction of value systems. However, until now, there have not been enough well-grounded, field-tested approaches to how climate change challenges and appropriate adaptation or mitigation measures could more intensively and effectively be integrated in secondary school education. In addition, there are not many empirical studies on how these kinds of interventions could be implemented together with an accompanying impact assessment. In fact, there are still major gaps in terms of understanding how to really engage young people in climate change issues. Although there is a large amount of general literature and social-psychological models and theories on variables influencing human behaviour and behavioural change (Jackson 2005; Maio et al. 2007; Darnton 2011), there are many aspects of this body of knowledge where no direct evidence is yet available regarding young people. The overall question in implementing educational interventions at school is therefore: which communication strategy is to be used in order to achieve the best and most sustainable results? As a first tentative answer, this paper argues that a change of young people's mind-set towards pro-environmental behaviour can be triggered by positive solution-oriented approaches, particularly by positive and solution-oriented messages, rather than by negative framing of climate change (see 2.1).

\section{Theoretical background and methodological approach}

\subsection{Deficiencies of climate change communication with threatening frames}

A considerable number of studies in the past decade have identified success factors as well as pitfalls of climate change communication (Corner 2014; O'Neill \& Nicholson-Cole 2009; Moser 2009; Spence \& Pidgeon 2009; Wolf \& Moser 2011). It seems impossible to neutrally present climate change issues and energyrelated aspects without some kind of context (Spence \& Pidgeon 2010; Hulme 2009; Thaler \& Sunstein 2008). Therefore, scholars such as Spence \& Pidgeon

Barbara Hinger (Hg.), Zweite „Tagung der Fachdidaktik“ 2015.

Sprachsensibler Sach-Fach-Unterricht - Sprachen im Sprachunterricht.

(C) 2016 innsbruck university press, ISBN 978-3-903122-51-2, DOI 10.15203/3122-51-2 
(2010) argue that the way in which information is 'framed' is paramount. Framing allows for a didactical reduction of complex issues, stressing particular aspects and thus providing arguments that let audiences rapidly identify why an issue may be relevant to them (Nisbet \& Mooney 2007).

One of the factors that has led to strong debates in this context is the use of fear, guilt or 'alarmism' in order to attract public attention to the topic of climate change (Ereaut \& Segnit 2006; De Hoog et al. 2005; Lowe et al. 2006; O’Neill \& Nicolson-Cole 2009). Scaring people in order to change their behaviours has indeed been used as a persuasive strategy by several actors (O'Neill et al. 2009; Witte 1994; Bleicher 2012). Mass media has discovered the topic of global climate change from the very beginning for its own interests, often deliberately blowing up scientific findings and thus contributing to the hype of willingly tracing catastrophes and the end of world settings. There are also a great number of movies that display apocalyptic scenarios. While some of them can be attributed to the category of science-fiction, aiming, above all, at entertaining spectators through exaggerated scenarios of planet-destroying tsunamis or sudden dramatic disruptions of the North Atlantic Current (e.g. Roland Emmerich's "The day after tomorrow"), others, especially recently issued documentaries (such as AlGore's "An inconvenient truth") deliver less fantastic and more scientific-based sceneries of consequences of climate change. Still, both types use the shocking principle and the 'doom and gloom'-mood in order to alarm people to the environmental situation of our planet.

Several scientific studies and articles, however, point out the problems connected with "fear appeals" (Witte 1994) and argue that apocalyptic representations of climate change may rather be counterproductive. In fact, if they seem to have a certain potential for attracting people's attention to climate change, "fear is generally an ineffective tool for motivating genuine personal engagement” (O’Neill \& Nicholson-Cole 2009). Hulme (2009) argues that a linguistic repertoire of words such as 'catastrophe', 'terror', and 'danger', which is routinely used in many climate change communication campaigns, is disengaging ordinary people. A governmental campaign in the UK has been heavily criticized for targeting children with inappropriate and scary frames about climate change (Sweney 2009).

Barbara Hinger (Hg.), Zweite „Tagung der Fachdidaktik“ 2015.

Sprachsensibler Sach-Fach-Unterricht - Sprachen im Sprachunterricht.

(C) 2016 innsbruck university press, ISBN 978-3-903122-51-2, DOI 10.15203/3122-51-2 
Instead of getting stuck at the "real, pressing danger" stage, otherwise known as the "tragic narrative" (Kloor 2011), climate change communication should rather focus on finding solutions and on breaking down the scope of action to the personal level. The use of nonthreatening imagery and messages that link to individuals' everyday emotions and concerns are thus regarded to be much more engaging. In doing so, individuals are more likely to find their own relationship and personal role with the issue instead of disengaging in the face of seemingly futile attempts to change the tide of events.

As a result of the aforementioned findings, this paper aims at stressing a specific approach to communicating climate change topics at school: the importance of framing them with positive and solution-oriented lines of action. This has been pursued in the research-education cooperation ActAdapt by designing a sixmonth intervention at three secondary schools in Tyrol, Austria, where students are, according to a moderate-constructivist understanding of learning, engaged in inquiry-based project work and research-exchange workshops with scientists, teachers and representatives from business and administration (cf. 3 Implementation of ActAdapt). In this respect, framing of climate change is not understood at a microlinguistic level but is rather to be seen in a macrolinguistic or sociolinguistic way. Therefore, the study does not particularly take into account language systems as abstract entities but rather looks at how linguistic settings and linguistic meaning function within a human social system (Matthews 2002).

In what follows, the theoretical background and the methodology used for the intervention and its evaluation will be outlined. Subsequently, the practical implementation of the six-step intervention is described in more detail before the results of the evaluation will be presented. Furthermore, the effectiveness of the intervention and its implications on the basis of the evaluation results are discussed.

\subsection{Moderate constructivist principles}

According to the principles of a moderate-constructivist learning theory, students are motivated to elaborate their own scientific questions, regarding different aspects of climate change and energy-related topics, and to develop possible

Barbara Hinger (Hg.), Zweite „Tagung der Fachdidaktik“ 2015.

Sprachsensibler Sach-Fach-Unterricht - Sprachen im Sprachunterricht.

(C) 2016 innsbruck university press, ISBN 978-3-903122-51-2, DOI 10.15203/3122-51-2 
solutions autonomously. In a constructivist learning process, learners adopt the role of seekers and problem solvers, and produce their own products by inquiring, taking decisions, collaborating, and using high level analytical skills and their individual creativity (Demirel 2005; Dunlop \& Grabinger 1996). Moderate constructivism does not completely leave out instruction (in contrast to a radical comprehension of constructivism), but stresses that learners must be provided with learning environments which enable subject-specific construction processes (Mandl 2006; Riemeier 2007). It has been found that learning situations are particularly effective when they are closely interlinked with lifeworld perceptions (Duit 1995; Kattmann 2003). Hence, the basic idea of a moderate constructivist approach is to take into account the subjective perspectives of the students and to open up the path for an individual approach of the students' concepts towards scientific models.

As formal school education does not always offer this kind of settings, the intervention discussed here has been designed specifically in order to create this kind of favourable contexts and to address social, motivational and emotional factors of learning in the sense of moderate constructivism (Posner, Strike, Hewson et al. 1982; Pintrich, Marx \& Boyle 1993).

Another important aspect of moderate constructivist learning is the transformation of theoretical knowledge into practical know-how. This has been guaranteed during the intervention not only through data collection and analysis by the students themselves, but also through their team-work with specialists and the presentation of their project results to a huge audience at the end of the six-month intervention. The peer work and regular exchanges of the students with scientists, economists and politicians is indeed an outstanding element of the intervention's underlying concept, as it allows to step aside of the traditional imposing way of knowledge-transfer from the teacher to the students towards a more motivating and active learning at eye level. As a consequence, students are likely to independently perceive the need to adopt more sustainable ways of living and to decide for themselves which values and behavioural patterns will be important for them in the future.

In this sense, the overall aim of the intervention was to develop and test innovative approaches of climate change communication and learning through a

Barbara Hinger (Hg.), Zweite „Tagung der Fachdidaktik“ 2015.

Sprachsensibler Sach-Fach-Unterricht - Sprachen im Sprachunterricht.

(C) 2016 innsbruck university press, ISBN 978-3-903122-51-2, DOI 10.15203/3122-51-2 
number of different workshops, intensive group-work periods, and exchanges with scientists and specialists.

\subsection{Evaluation methodology}

An online survey (available at: https://www.soscisurvey.de/Act-Adapt/ [29.03.2016]) has been carried out with all students at the beginning (pre-test) and at the end (post-test) of the six-month intervention. This quasi-experimental pre-test-post-test design consists of quantitative as well as qualitative items. Similar to other evaluation studies (e.g. Angus \& Watson 2009; Voelkel 2013), it comprises both summative as well as formative evaluation elements (Scriven 1991).

The pretest has manifold functions: First, it serves to define the cognitive, affective, and behavioural status-quo of the students participating in the intervention. Second, the results of the pretest provide information about the students, which are needed to develop the intervention target-group oriented and thus contributes to the quality assurance of the study. Finally, the pretest provides a benchmark to later compare the results to those of the post-test and to identify imminent impacts of the intervention.

In addition to the pre-test-post-test comparison, qualitative interviews were carried out and analysed. However, due to space constraints, they have not been included in this paper but can be found in Gruber (2015).

Moreover, the insights gained through the evaluation should serve to identify effective educational instruments for the classroom and to determine factors for the successful conception of research-education cooperation. The results of this study will thus primarily be passed on to student teachers, senior teachers and other institutions in the field of education.

\section{Implementation of ActAdapt}

ActAdapt is an initiative carried out within an Austrian cooperation project between major energy-supply companies, several scientific institutions, and three different schools in Tyrol, Austria. It was conceived as an intervention lasting 6

Barbara Hinger (Hg.), Zweite „Tagung der Fachdidaktik“ 2015.

Sprachsensibler Sach-Fach-Unterricht - Sprachen im Sprachunterricht.

(C) 2016 innsbruck university press, ISBN 978-3-903122-51-2, DOI 10.15203/3122-51-2 
months, representing thus a profound engagement with the specific topics of climate change and energy, and carried out in three schools in Western Austria. 68 students aged between 16 and 17 took part in the intervention, which was structured into six steps, each with different activities and specific learning goals. In this chapter, the implementation of this initiative will be outlined practiceoriented to demonstrate how the theoretical aspects of climate change communication in chapter 2 have been translated into action on the ground in the context of ActAdapt.

\subsection{A long-term six-step intervention model}

Short-term exposures to environmental topics have in general appeared to be rather ineffective in encouraging the development of responsible environmental behaviour (McCutcheon 1981; Partian 1979). The intervention described here was thus designed as a long-term antecedent intervention with regular, succeeding meetings over a period of six months between September 2013 and March 2014. Thematically as well as organisationally, the intervention was developed and implemented in line with the regular school curriculum but also enriched by additional activities inside and outside of the classroom (e.g. field-trips, research tasks like carrying out interviews or taking pictures where consequences of climate change can be seen). In total, 20 hours of classroom activities were carried out between September 2013 and March 2014 in the framework of the regular teaching schedule. Additionally, three workshops of 4-6 hours each - including project work accompanied by scientists, specialists and representatives of politics, economy and administration, one field trip to a hydropower plant, and 4 periods of independent out-of-classroom activities for the students - were carried out. The program was structured as a six-step intervention model (see figure 1). Every step included different activities and learning contexts and addressed different competencies and educational goals on a micro-level, such as the development of a pro-environmental attitude (step $1 \& 2$ ), the adoption of personal responsibility (step $3 \& 4$ ) or the acquisition of action skills and action strategies (step $5 \& 6$ ). In combination, these steps are thought to have a positive effect on the development of the students'

Barbara Hinger (Hg.), Zweite „Tagung der Fachdidaktik“ 2015.

Sprachsensibler Sach-Fach-Unterricht - Sprachen im Sprachunterricht.

(C) 2016 innsbruck university press, ISBN 978-3-903122-51-2, DOI 10.15203/3122-51-2 
self-efficacy and their intention to act (macro goal), leading then to the overall strategic goal of the intervention: to facilitate pro-environmental behaviour.

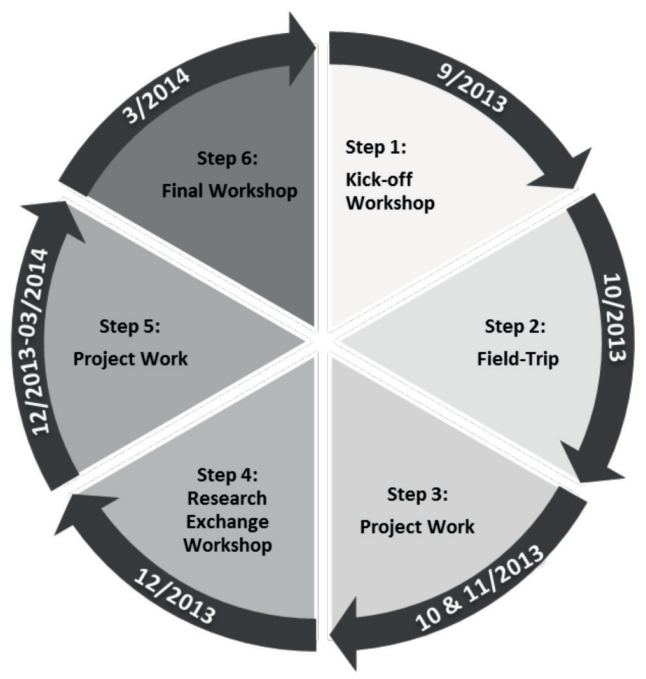

Figure 1: Progress chart of the 6-steps-implementation of ActAdapt (Figure M. R. et al.)

\subsection{Steps 1 \& 2: Kick-off Workshop and Field Trip}

The initial step of the intervention was a four-hour kick-off workshop (step 1, cf. figure 1) between the end of September and the beginning of October 2013 (the exact dates varied in dependence of the school schedule). The participants of the kick-off workshop were asked to choose whether they wanted to take part in a 'photo-safari' or a household survey. Each of the two groups consisted of 4-5 students. Both groups received the same questions about climate change (impacts), mitigation measures, energy use, energy generation and renewables, presented here:

(1) Where can you see climate change?

(2) Whose responsibility is climate change?

(3) What can you do against climate change?

(4) Where do you personally take action against climate change?

(5) Where can you see energy? 
(6) Where can you see renewable energy?

(7) Where could you save energy?

(8) Where could you generate energy?

(9) Invent your own question(s).

While the 'photo-safari' group was asked to answer these questions by taking self-explaining pictures, the second group had to conduct interviews in specific households. They also had to complete the set of given questions with two further individual questions. The collected data was then examined, analysed and processed into short presentations, in which the participants discussed their findings and gave individual recommendations (step 1, cf. figure 2). The hands-on workshop had been designed according to the results of the pre-test and contained many participatory basic content elements (climate change \& energy topics) as well as methodological elements (inquiry-based learning).

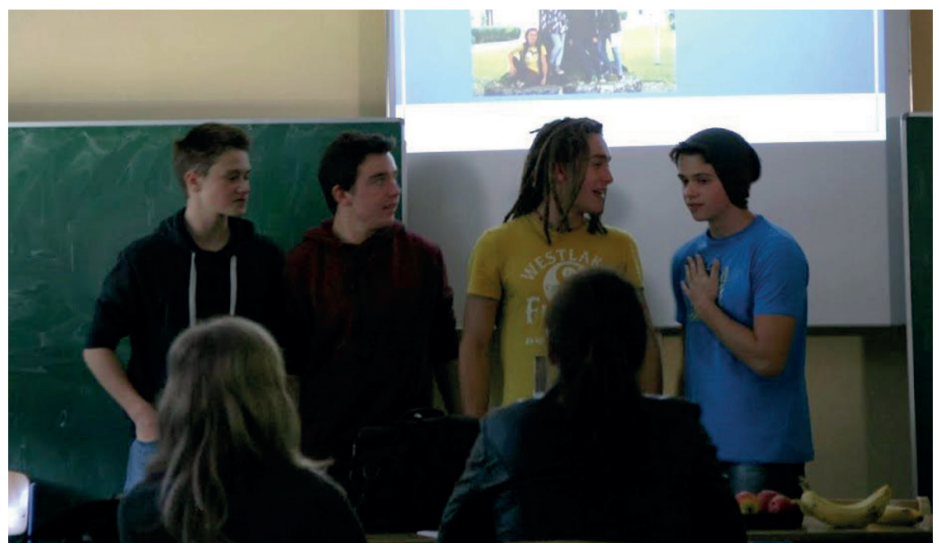

Figure 2: Group of students presenting individual results of the „photo-safari“" to their classmates (Photo M. R. et al.)

The field-trip to a hydropower plant (step 2, cf. figure 3) of the energy supplier TIWAG - Tiroler Wasserkraft AG in Silz, Tyrol, took place two weeks later. The participants spent half a day at the plant, learning about the functional principle of hydropower plants as well as their political, economic, social and ecologi- 
cal dimensions at local, national and European level. By combining workshop and field-trip, students were likely to seize the importance of local aspects of climate change and energy topics. Furthermore, they could discover their individual scope of action and, in doing so develop awareness of their own ability to contribute to change through their behaviour.

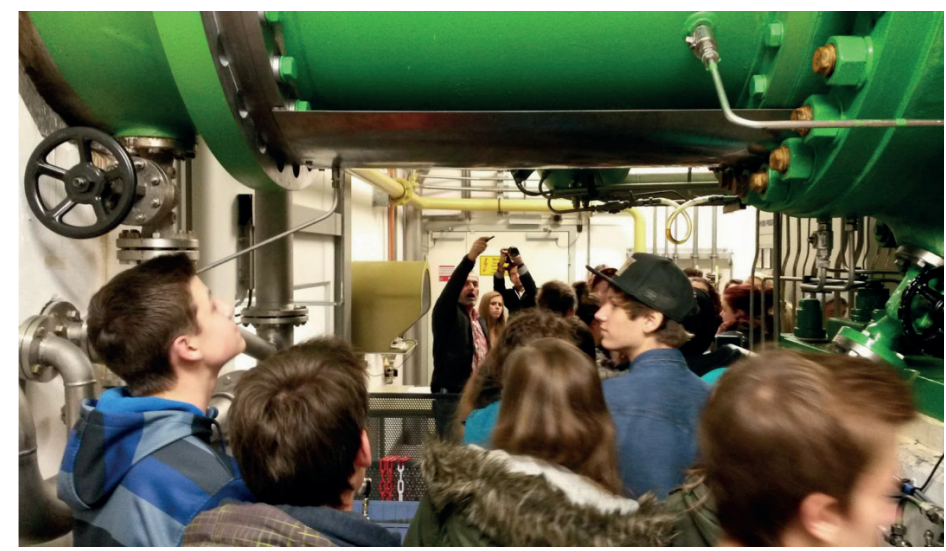

Figure 3: Students visiting a hydropower plant of the energy supplier TIWAG-Tiroler Wasserkraft AG (Photo M. R. et al.)

Both steps were conceived and carried out in combination, as they are thought to be complementary in an educational sense. The main objective of the kick-off workshop was to make students aware of the local aspects of climate change and their personal scope of action. This 'didactically' initiated attention among the participants accounted for the development of an initial situational interest and, in the sense of Mitchell (1993), thus also contained a catch-component. The hands-on outdoor experiences of the kick-off workshop and the field trip were expected to include such a catch-component and to provide motivational incentives. Instead of rigorously collecting all potential climate change impacts as well as every imaginable energy conservation measure, this activity intends to activate students' perceptions of and foreknowledge about climate change and energyrelated aspects without dramatizing the severity of climate change impacts. As a result, it sets the ground to connect with new knowledge generated through indi- 
vidual experiences. Steps $1 \& 2$ convey a solution-oriented and proactive message as the students discover individually how much is already done in this respect (step 1), and collectively as they learn about one exemplary possibility (including all negative aspects) to generate renewable energy out of renewable resources right on their doorstep (i.e. hydropower).

\subsection{Steps 3 \& 4: Project Work and Research-Exchange Workshop}

After the topic-oriented introduction and the field-trip, the intervention proceeded with an extended phase of project work at school (step 3), which aimed at introducing the participants to the basics of scientific work. In classroom meetings over the course of four weeks, the participants were invited to learn about the basic principles of scientific research, to formulate their own research questions in small groups, and to find adequate research methods for their individual research projects on climate change and/or energy that they would develop throughout the next three steps to come. Additionally, in group work, they encountered basic information about climate and energy systems ranging from e.g. global impacts of climate change over national strategies for energy efficiency to local land-use conflicts in connection with renewables.

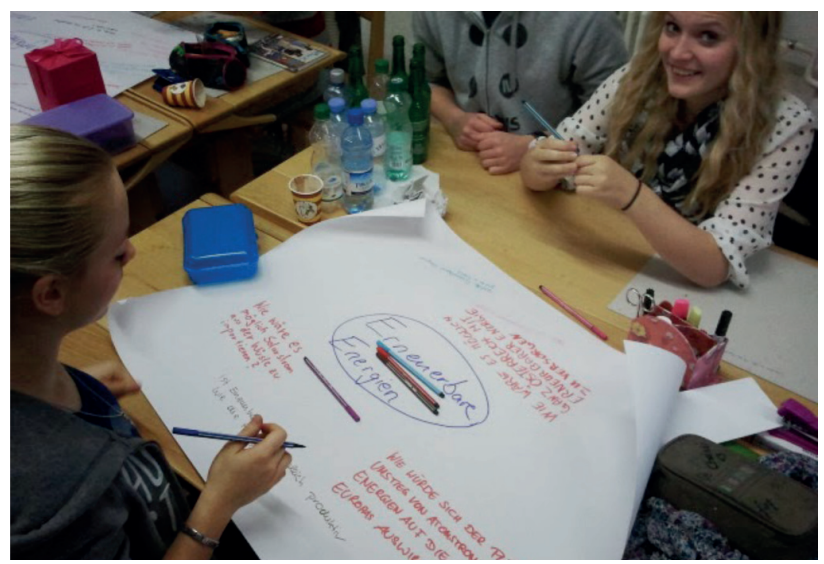

Figure 4: Students during a brainstorming about potential research questions for their individual projects (Photo M. R. et al.) 
The individual six-month research projects were supposed to lead to the development of a deeper individual interest of the students in climate change and energy topics, as well as to the construction of meaning through the application of their research proposals in lifeworld contexts (i.e. the constructive aspect of the moderate-constructivist idea of learning). Another important point here is self-determination, that is, the learning process should not be externally determined but stimulated by providing a suitable environment which allows for self-determination, as research group work does. Moreover, the individual, social and situated aspects were taken into account, following the idea that knowledge production and competence development is closely interlinked with the individual cognitive system of the learner, but also with social interactions within the groups and contextual experiences. During step 3, the students made insofar wide-ranging decisions, as they had to stick to the research focus they determined here, throughout the rest of the project. The constitution of the research questions was entirely up to the students, except for the fact that the questions had to be connected to their personal scope of action. This ensured a solution-oriented framing of their work, yet left the final decision up to them. Setting the students' research foci under a positive light was the basis for all of the following steps. This guaranteed that they would more likely focus at finding solutions instead of lamenting impacts throughout all of the following steps.

As a follow-up to the classroom meetings, acknowledged experts from science and practice in the climate change and energy domain were invited to a one-day research-exchange workshop "School meets Science and Practice" (step 4) in December 2014. The experts first introduced their personal area of activity and then discussed the students' research proposals and their scope of action in the light of current developments in the debate about climate change and energy topics. Afterwards, the experts assisted the students in developing and refining their own research proposals according to the received feedback (cf. figure 5).

Barbara Hinger (Hg.), Zweite „Tagung der Fachdidaktik“ 2015.

Sprachsensibler Sach-Fach-Unterricht - Sprachen im Sprachunterricht.

(C) 2016 innsbruck university press, ISBN 978-3-903122-51-2, DOI 10.15203/3122-51-2 


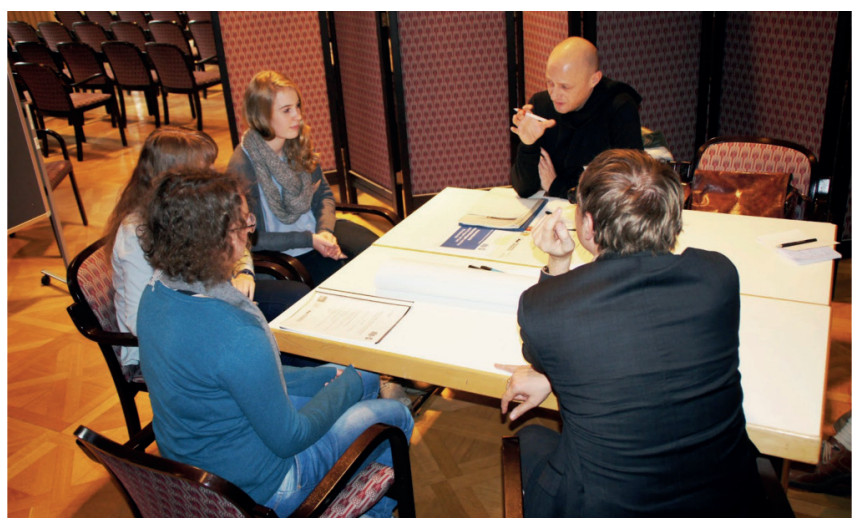

Figure 5: Experts and students during workshop „School meets Science and Practice“ (Photo M. R. et al.)

The workshop was organised as an exchange platform with a flat hierarchy in order to lower barriers between experts and students. Here, the students not only had the possibility to deepen their knowledge on specific aspects of their research question, but also to really get into the process of doing research themselves by directly discussing topics with experts face to face.

Whereas step 1 and 2 (kick-off workshop and field-trip) tended to raise the interest of the students through a first confrontation with certain topics and by making a global phenomenon visible on a local scale, the project work and research-exchange workshop (step 3 and 4) targeted the transformation of the so far acquired theoretical knowledge into skills. This was achieved mainly by testing and transferring the acquired knowledge onto the students' specific research questions and through the discussions that took place throughout the workshop (Riede et al. 2014). In active discussions in small groups, the students had the possibility to develop the necessary familiarity with scientists and experts so as to adopt a more scientific notion of their topics. The involved experts had been particularly briefed to not intimidate the students by stressing the severity and urgency of the topic, but rather collaborate with them on the basis of their research projects. The selection of experts who participated in the workshop was carefully considered. Except for one climatologist, only 
experts involved in climate change solution-oriented positions (e.g. climate protection officers, energy consultants, energy economists, politicians, sociologists) participated.

Another important goal of the research-exchange workshop was the development of a sense of personal responsibility amongst the students. According to the "Model of Responsible Environmental Behavior" (Hines et al. 1987), people with a greater sense of personal responsibility are more likely to engage in proenvironmental behaviour. In view of the latter as overall final goal, the students were at all times asked to develop their own perspectives, priorities and possible solutions, and to present them to the public at the end of the project.

\subsection{Steps 5 \& 6: Project Work and Final Workshop}

Following the exchange with the experts, students were asked to accomplish their research proposals by defining the methodology to be adopted for data collection and analysis (step 5). The research was organized in two parts: first, data was collected over a period of one month, mostly through personal observation, literature search, surveys and qualitative interviews. Then, the data collected was examined and analysed according to scientific standards. Here, the students were assisted by their teachers but also by visiting scientists during regular meetings every two weeks.

In terms of the topics chosen, the students' research projects were very diverse and ranged from assessments of mobility behaviour or nutrition of schoolmates to the question of whether fitness centres could cover their electricity consumption through the use of their gym equipment; or global questions like TTIP's impact on climate change. The insights gained through the students' research constituted the groundwork for the formulation of individual recommendations of the students regarding how to deal with challenges connected to climate change and energy.

At the end of the six-month intervention, the final all-day workshop (step 6) served as a platform for the presentation of the research carried out by the different groups. It enabled discussions between the students and invited representatives from the field of climate and energy science, practice and policy, as

Barbara Hinger (Hg.), Zweite „Tagung der Fachdidaktik“ 2015.

Sprachsensibler Sach-Fach-Unterricht - Sprachen im Sprachunterricht.

(C) 2016 innsbruck university press, ISBN 978-3-903122-51-2, DOI 10.15203/3122-51-2 
well as journalists, representatives of the university of Innsbruck and guests. The students presented their research as well as their most important results, and had the possibility to directly address decision makers in terms of recommendations as well as demands. The final presentation allowed not only to strengthen the students' social and communication skills but also led to a deepening of their understanding and knowledge of climate change topics as they could listen to the presentations of the other research groups and discuss their findings with their peer students.

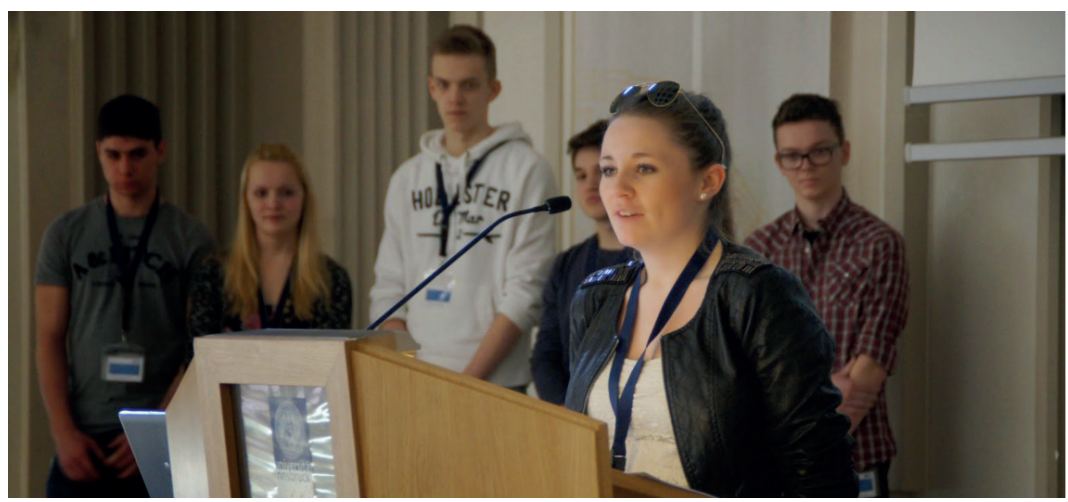

Figure 6: Group of students presenting their research results to decision makers (Photo M. R. et al.)

The last two steps $5 \& 6$ were essential as they attempted to lead to the acquisition of action skills and the increase of knowledge of action strategies among the participating students. During the entire intervention process, but most specifically in the final step 6, students were enhanced to develop and experience competences by presenting their work in an official setting and by directly communicating with decision-makers from business, science and politics. Vogt (2007) describes this approach as an experience to use one's own action ability in order to cope with challenges and to satisfy given requirements ${ }^{1}$. This is closely related to the feeling of self-efficacy and depicts a significant component on the way to

1 The German term created by Vogt in this context is „Kompetenzerleben“. 
action. Furthermore, it was likely to raise the students' self-esteem, as they could experience that the experts took them seriously. A young person who has successfully experienced the feeling of being actually able to make a difference by being proactive and by setting initiatives will most likely develop self-confidence to take action on a regular basis..

\section{Evaluation Results}

The results gained on the basis of the post-test as well as through the pre-testpost-test comparison will be presented in what follows. While the entire research design evaluated numerous aspects, the study presented here only focused on a limited number of specific aspects. Two particular questions have been examined based on the post-test only: First, in which phase of the project do the students perceive to have learnt most? And second, how much did the students like the activities in each of the intervention's main phases? This part of the evaluation allows insights into the assessment of particular activities and thereby attempts to find out more about the students' experiences within the project.

In addition to this post-test assessment, the pre-test-post-test comparison concentrates on the impacts of the intervention. The aim here is trying to identify changes in personal affective as well as cognitive attributes of the students regarding climate change and energy-related issues. The evaluation does not allow for a comparison between two differently framed communication strategies, but it provides insights into the impacts of the framing chosen in ActAdapt and thereby allows for statements about the approval or disapproval of the framing approach. A summary of the statements collected in this evaluation process will then be interpreted in the discussion at the end of the paper.

\subsection{Evaluation results on the basis of the post-test}

The first question concerned the students' perception of their personal learning experiences throughout the different phases of the project. The results (cf. figure 7) clearly show that the majority of the students state to have learned most dur-

Barbara Hinger (Hg.), Zweite „Tagung der Fachdidaktik“ 2015.

Sprachsensibler Sach-Fach-Unterricht - Sprachen im Sprachunterricht.

(C) 2016 innsbruck university press, ISBN 978-3-903122-51-2, DOI 10.15203/3122-51-2 
ing the main project-work phases, which took place outside the regular school context (steps 1, 2, 4 and 6), and especially in the research exchange workshop (step 4) in the middle of the project. In general, the results reveal a positive evaluation of the entire project and show that the majority of students perceived to have learned something through the project (cf. figure 7).

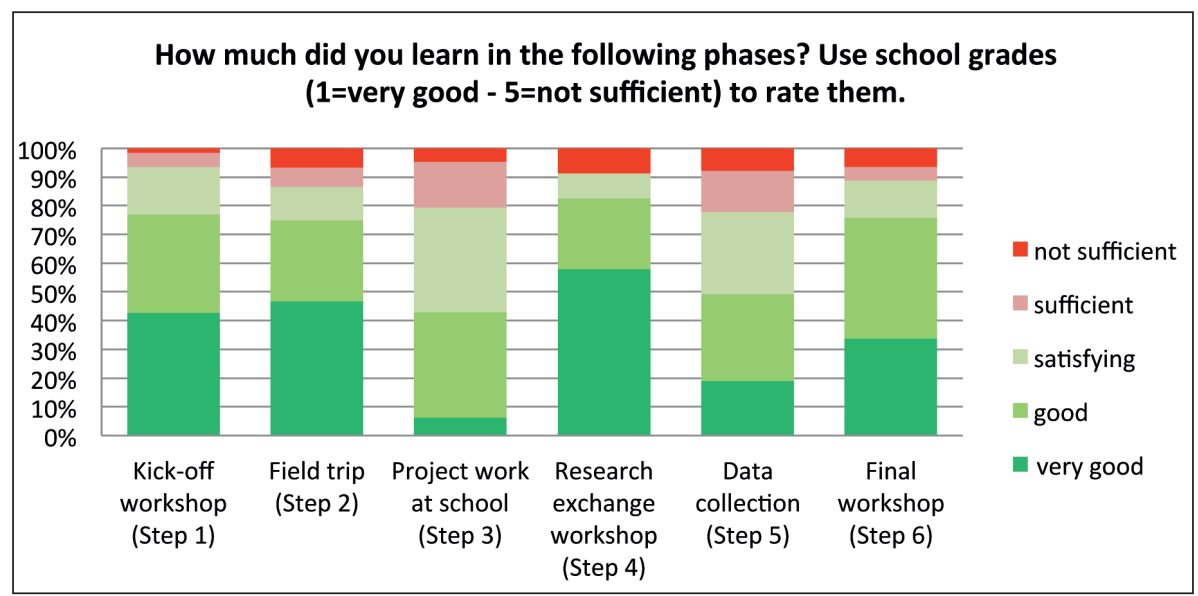

Figure 7: Representation of the student's answers to the question: How much did you learn in each of the phases of the intervention?

When asked which phase the students appreciated the most (cf. figure 8), the results showed a similar picture. The research-exchange workshop (step $4=74 \%$ ) seems to have been, by far, the most appreciated phase of the project. The final workshop (step $6=73 \%$ ), as well as the field trip to the hydropower plant (step $2=68 \%$ ), have been evaluated similarly. In contrast, the preparation for it (step $3=46 \%$ ) as well as the following up (step $5=51 \%$ ) has only been appreciated by about $50 \%$ of the students. Summarizing the students' rating for all six phases depicts a positive image of the project and shows that the majority of the students appreciated it. 


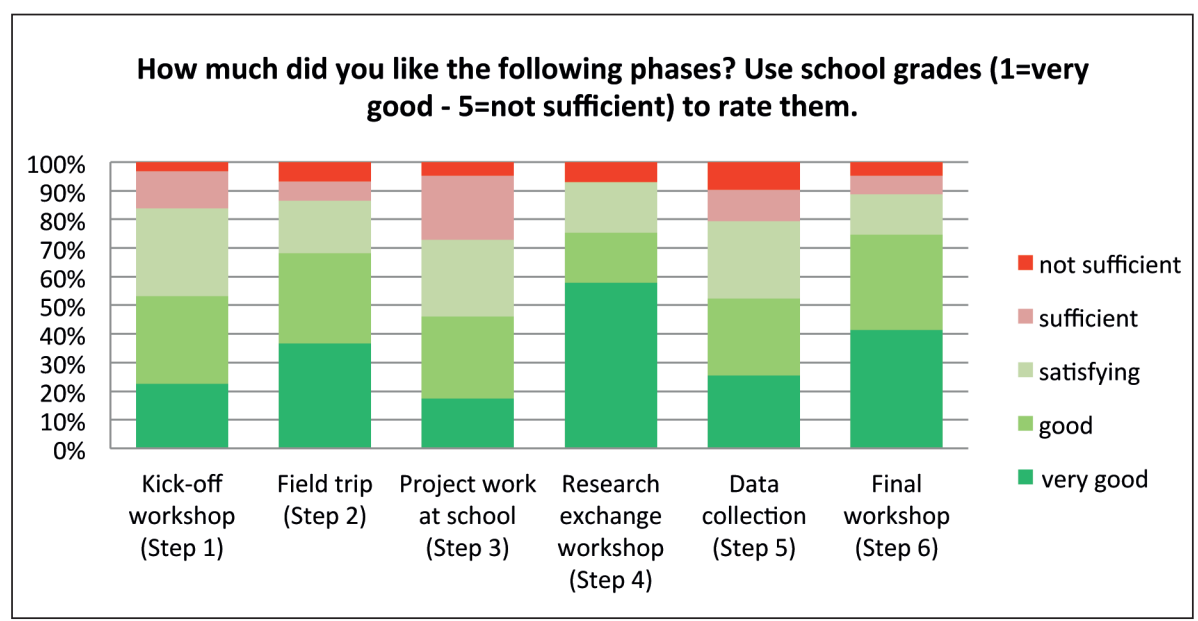

Figure 8: Representation of the student's answers to the question: How much did you like each of the phases of the intervention?

\subsection{Evaluation results on the basis of the pre-test-post-test comparison}

In addition to the insights gained through the analysis of the post-test, the pretest-post-test comparison aimed at identifying possible changes induced by the intervention. The main objective of this evaluation is to determine the degree to which each of the goals on the micro, macro and global level have been achieved and to measure the general impact of the intervention and its effectiveness. In the following, we will point out the main results of the evaluation regarding three issues in particular: i) personal awareness and interest, ii) personal scope of action, and iii) knowledge gain.

Regarding the impact of the intervention on the students' awareness and attitudes on an affective level (cf. table 1), the evaluation shows the following results: Regarding the item which asked the students to assess their energy awareness, the comparison of the medians of the pre-test with those of the post-test revealed a significant difference. In the post-test, the students declared their energy awareness to be significantly higher than in the pre-test (Item 1, p=.022). Also, their 
interest in the topic 'energy transition' has increased significantly in the post-test (Item 3, p=.018).

Table 1: Results of personal awareness and interest

\begin{tabular}{|c|c|c|c|c|c|}
\hline \multicolumn{2}{|l|}{ Item } & $\mathrm{N}$ & M & SD & $\mathrm{M}_{\mathrm{T} 2}-\mathrm{M}_{\mathrm{T} 1}$ \\
\hline \multirow{2}{*}{$\begin{array}{l}\text { 1. My personal energy awareness } \\
\text { is... } \\
\text { (i) }\end{array}$} & T1 & 84 & 3.32 & 1.01 & \multirow{2}{*}{$-.36 *$} \\
\hline & $\mathrm{T} 2$ & 88 & 2.97 & 1.01 & \\
\hline \multirow{2}{*}{$\begin{array}{l}\text { 2. My personal climate awareness } \\
\text { is... } \\
\text { (i) }\end{array}$} & T1 & 84 & 3.08 & .93 & \multirow{2}{*}{-.14} \\
\hline & $\mathrm{T} 2$ & 88 & 2.94 & 1.02 & \\
\hline \multirow{2}{*}{$\begin{array}{l}\text { 3. How interested are you in the topic } \\
\text { of 'energy transition'? } \\
\text { (ii) }\end{array}$} & T1 & 84 & 3.20 & 1.24 & \multirow{2}{*}{$-.42 *$} \\
\hline & $\mathrm{T} 2$ & 88 & 2.78 & 1.03 & \\
\hline \multirow{2}{*}{$\begin{array}{l}\text { 4. How interested are you in the topic } \\
\text { of 'climate change'? } \\
\text { (ii) }\end{array}$} & T1 & 84 & 2.66 & 1.12 & \multirow{2}{*}{.00} \\
\hline & $\mathrm{T} 2$ & 88 & 2.66 & 1.12 & \\
\hline
\end{tabular}

Note: T1 =pre-test; T2=post-test; $\mathrm{N}=$ Sample Size; M=Mean Score; SD=Standard Deviation;

$\mathrm{M}_{\mathrm{T} 2}-\mathrm{M}_{\mathrm{T} 1}=$ Difference between $\mathrm{M}_{\mathrm{T} 2}$ and $\mathrm{M}_{\mathrm{T} 1 ;} * * \mathrm{p}<.01 ;{ }^{*} \mathrm{p}<.05$

(i) $1=$ very high, $2=$ high, $3=$ rather high, $4=$ rather low, $5=$ low, $6=$ very low

(ii) $1=$ very interested, $2=$ interested, $3=$ rather interested, $4=$ rather uninterested, $5=$ uninterested, $6=$ very uninterested

In terms of the students' self-perception regarding the personal locus of control and possibilities to influence climate change consequences, table 2 illustrates that there is a high consensus among the students - before as well as after the intervention - that science and technology will not solve environmental and climate problems alone. Instead, most of the students rather believe that a behavioural 
change is required (item 6). Additionally, most students tend to agree that it is not too late to act on climate change (item 5). From the medians in item 5, a generally high faith in the possibilities to act collectively on a regional scale can be detected, both before and after the intervention. Regarding the impact of the intervention to change one of these aspects among the students, the results reveal that this could not be achieved significantly throughout the six months of the project.

Table 2: Results of personal locus of control

\begin{tabular}{l|l|r|r|r|r}
\hline \multicolumn{2}{l|}{} & $\mathrm{N}$ & $\mathrm{M}$ & $\mathrm{SD}$ & $\mathrm{M}_{\mathrm{T} 2}-\mathrm{M}_{\mathrm{T} 1}$ \\
\hline \multirow{2}{*}{$\begin{array}{l}\text { Item } \\
\begin{array}{l}\text { 5. It's already too late to act on } \\
\text { climate change. }\end{array}\end{array}$} & $\mathrm{T} 1$ & 84 & 3.33 & .84 & .16 \\
\cline { 2 - 5 } & $\mathrm{T} 2$ & 88 & 3.49 & .69 & \\
\hline \multirow{2}{*}{$\begin{array}{l}\text { 6. I don't think a change of my } \\
\text { personal behaviour would make a } \\
\text { difference on climate change. }\end{array}$} & $\mathrm{T} 1$ & 84 & 2.80 & 1.00 & \\
\cline { 2 - 5 } & $\mathrm{T} 2$ & 88 & 2.94 & .98 & \\
\hline
\end{tabular}

Note: T1=pre-test; $\mathrm{T} 2=$ post-test; $\mathrm{N}=$ Sample Size; $\mathrm{M}=$ Mean Score; $\mathrm{SD}=$ Standard Deviation; $\mathrm{M}_{\mathrm{T} 2}{ }^{-}$

$\mathrm{M}_{\mathrm{T} 1}=$ Difference between $\mathrm{M}_{\mathrm{T} 2}$ and $\mathrm{M}_{\mathrm{T} 1 ;} * * \mathrm{p}<.01 ;{ }^{\mathrm{p}}<.05$

$1=$ agree, $2=$ rather agree, $3=$ rather disagree, $4=$ disagree;

In terms of knowledge of issues (table 3), no significant differences could be detected between the distribution of the groups in the pre-tests and post-tests. The results only show that the students' knowledge of the annual global mean surface temperature is slightly higher than in the case of sea level rise. However, both items clearly show a lack of knowledge among the students when it comes to global climate change phenomenon such as sea-level or global temperature rise. 
Table 3: Results of knowledge of issues

\begin{tabular}{|c|c|c|c|c|}
\hline Item & & $\mathrm{N}_{\text {correct }}$ & $\mathrm{N}_{\text {almost correct }}$ & $\mathrm{N}_{\text {incorrect }}$ \\
\hline \multirow{3}{*}{$\begin{array}{l}\text { 7. How much will sea level rise until } \\
2050 \text { according to scientists? }\end{array}$} & $\mathrm{T} 1$ & 17 & 26 & 41 \\
\hline & $\mathrm{T} 2$ & 21 & 31 & 32 \\
\hline & & & \multicolumn{2}{|c|}{$\chi^{2}=2.228, \mathrm{df}=2, \mathrm{p}=.33$} \\
\hline \multirow{3}{*}{$\begin{array}{l}\text { 8. How much will annual global mean } \\
\text { surface temperature rise until } 2050 \\
\text { according to scientists? }\end{array}$} & $\mathrm{T} 1$ & 21 & 49 & 14 \\
\hline & $\mathrm{T} 2$ & 23 & 46 & 15 \\
\hline & & & \multicolumn{2}{|c|}{$\chi^{2}=.251, \mathrm{df}=2, \mathrm{p}=.88$} \\
\hline
\end{tabular}

Note: $\mathrm{df}=$ Degrees of Freedom; Sample Size $=84 ; \mathrm{T} 1=$ pre-test; $\mathrm{T} 2=$ post-test

Table 4 summarizes the most significant changes achieved through the project at cognitive level. The students' knowledge about climate change mitigation measures (item 9, $\mathrm{p}=.001$ ) as well as their knowledge whether these measures are sustainable at all (item 10, $\mathrm{p}=.001$ ) have reportedly increased highly significantly. The students' volition to act and do something against climate change could not be increased through the project but has been rather high before as well as after the project. 
Table 4: Results of knowledge of measures

\begin{tabular}{|c|c|c|c|c|}
\hline Item & & M & $\mathrm{SD}$ & $\mathrm{M}_{\mathrm{T} 2}-\mathrm{M}_{\mathrm{T} 1}$ \\
\hline \multirow{2}{*}{$\begin{array}{l}\text { 9. I don't know any climate change } \\
\text { mitigation measures. }\end{array}$} & $\mathrm{T} 1$ & 2.54 & .92 & \multirow{2}{*}{$.50 * *$} \\
\hline & $\mathrm{T} 2$ & 3.03 & .88 & \\
\hline \multirow{2}{*}{$\begin{array}{l}\text { 10. I don't know which climate } \\
\text { change mitigation measure is } \\
\text { sustainable at all. }\end{array}$} & T1 & 2.54 & 1.01 & \multirow[b]{2}{*}{$.41 * *$} \\
\hline & $\mathrm{T} 2$ & 2.94 & .88 & \\
\hline \multirow{2}{*}{$\begin{array}{l}\text { 11. I would like to do something } \\
\text { against climate change. }\end{array}$} & T1 & 2.14 & .84 & \multirow{2}{*}{.22} \\
\hline & $\mathrm{T} 2$ & 2.36 & .91 & \\
\hline
\end{tabular}

Note:T1 = pre-test; $\mathrm{T} 2=$ post-test; $\mathrm{N}=$ Sample Size; $\mathrm{M}=$ Mean Score; $\mathrm{SD}=$ Standard Deviation; $\mathrm{M}_{\mathrm{T} 2}{ }^{-}$

$\mathrm{M}_{\mathrm{T} 1}=$ Difference between $\mathrm{M}_{\mathrm{T} 2}$ and $\mathrm{M}_{\mathrm{T} 1 ;} * * \mathrm{p}<.01 ; * \mathrm{p}<.05$

$1=$ agree, $2=$ rather agree, $3=$ rather disagree, $4=$ disagree; $\mathrm{M}=$ Mean Score, ${ }^{*} \mathrm{p}<.01 ;{ }^{*} \mathrm{p}<.05$

\section{Discussion}

The students' assessment of the individual phases of the intervention through the post-test showed that the majority appreciated the project and reported to have learned something by participating in it. Looking closer at the results, it becomes undoubtedly obvious that phases such as the workshops or the field trip, outside the well-known school reality, receive more positive ratings and are perceived to have more learning potential than rather conventional settings like project work in the classroom. At first glance, this doesn't seem very surprising as it can be expected that a variation of the regular school routine might always be welcomed by students since it might be associated with a more easy-going alternative to traditional lessons. Hence, the interpretation of the results of the post- 
test could end here. However, looking at the characteristics of the particularly positively rated phases of the intervention in terms of their learning potential, it can be detected that these phases have neither been less cognitively challenging (e.g. discussions with scientists at research-exchange workshop) than regular lessons nor have they demanded less active participation of the students (e.g. conducting household interviews and holding presentations at kick-off workshop). Therefore, we conclude from the results that students in our case study especially appreciated tasks which have been cognitively challenging and demanded a lot of active participation and input. Additionally, the tasks in these phases had a particularly strong connection to the students' personal life context and allowed for a lot of personal responsibility. This corroborates the hypothesis stated by several scientists such as Pintrich, Marx \& Boyle (1993) or Kattmann (2003), according to which learning settings are most effective when they are linked to the personal life context perceptions and when they offer a favorable context for addressing social, motivational and emotional factors of learning (cf. point 2.2). It also corresponds to the ideas of process learning that underlie conceptual change theories as well as moderate constructivism in general (cf. Krüger 2007; cf. Riemeier 2007). In this learning process, one phase follows the next and thus allows the gradual and individual construction of new notions and attitudes. During the kick-off workshop, for instance, the lifeworld of the students was addressed directly and the fact that the students had to complete specific tasks in the field, required them to quickly develop and use their own competencies instead of listening to a 'traditional lecture'. Moreover, the workshops included cognitive and emotional components as well as a direct confrontation with their surrounding environment.

It is evident that this part of the evaluation only provides general information about the extent to which the different phases in particular and the entire project together can be approximately understood as success or failure. This approves the applied communication strategy, characterized through its positive and solution-oriented framing, as an approach that is, to a high extent, appreciated and interpreted as beneficial by the target group. Even so, it does not allow for any statement about the impact of the intervention among the participating students.

Barbara Hinger (Hg.), Zweite „Tagung der Fachdidaktik“ 2015.

Sprachsensibler Sach-Fach-Unterricht - Sprachen im Sprachunterricht.

(C) 2016 innsbruck university press, ISBN 978-3-903122-51-2, DOI 10.15203/3122-51-2 
Only through the pre-test-post-test comparison we can attempt to draw conclusions about the interventions' impacts.

Yet, the study design does not allow for the comparison of different framing approaches and showing which one works most effectively. However, looking closely at the results, traces reveal the impacts of a positive and solution-oriented framing of climate change. While "doom and gloom" framing might more likely lead to an increase in the attention for climate change (O’Neill \& NicholsonCole 2009; Kloor 2011), the here described approach does not follow the pursuit to raise the attention for climate change but rather targets to put the focus on solution-oriented aspects connected with climate change - that is energy-related issues. The results reveal that the students' energy awareness has been raised significantly, while their climate awareness has not. At the same time, their interest in the topic of energy transition has also increased significantly, while their interest in the topic of climate change did not alter at all. Although it cannot be traced back, it appears as a result of the framing approach applied in this context.

Similar observations can be made by looking at the results of the intervention at cognitive level. No significant differences could be detected between the students' knowledge of the rise of the annual global mean surface temperature or sea-level-rise. Both items clearly show a lack of knowledge among the students when it comes to global climate change phenomenon. However, when they are asked about their knowledge of climate change mitigation measures as well as their knowledge about the sustainability and potential of these different measures, the evaluation shows significant changes after the intervention. This underpins the positive impact of the solution-oriented framing and thereby proves its success in preparing young people for climate change challenges by focusing on solutions rather than dramatizing impacts.

\section{Conclusion}

From a policy perspective, responding to climate change challenges can essentially be divided into two directions. Behavioural changes resulting from light-

Barbara Hinger (Hg.), Zweite „Tagung der Fachdidaktik“ 2015.

Sprachsensibler Sach-Fach-Unterricht - Sprachen im Sprachunterricht.

(C) 2016 innsbruck university press, ISBN 978-3-903122-51-2, DOI 10.15203/3122-51-2 
house bottom-up initiatives on the one side, and all-encompassing regulatory action through top-down legislation on the other side (Ockwell et al. 2009; Sprinz 2011). Reconcilably facilitating public acceptance of regulation and simultaneously stimulating grass-roots action through affective and rational communication and education activities is crucial. In fact, by framing climate change in a positive and solution-oriented manner both directions can be served. It sets the ground for top-down legislation by raising acceptance for relevant measures and makes individuals familiar with options for implementing mitigation measures in their everyday life. Therefore, addressing climate change by integrating energyrelated aspects in formal school education can be beneficial for both directions.

However, it is also clear that this is only the beginning of a process that requires more time to really lead to a consequent and sustainable change of the behaviour and mind-set of the students. Reasons for this are, first, that systematic and targeted integration of climate change topics into school education has only just been initiated. Böhm (2009) found that the extent to which Austrian schoolbooks as well as curricula cover the topic varies strongly. Second, behavioural change as a means for societal transformation is a long and slow process and subjected to a variety of factors. Personal engagement usually comes along with a strong personal experience or with the influence of important people in the person's direct environment (e.g. family or friends). It is often a long-lasting process that goes hand in hand with the individual evolution as a person and citizen, the acquisition of a solid self-confidence, and the will to engage in projects that go beyond the personal benefit. However, if we are convinced that a decision to adopt certain attitudes and behaviours can only be taken on the basis of a solid ground of knowledge, a set of relevant competencies, and a reflective capacity, it is also clear that these competencies are built up during adolescence and - to a high degree - in school context. In order to meet the challenges of a global energy transition, we thus need to reinforce evidence-based and field-tested interventions in school education that do not frighten and discourage students but rather empower and activate them to develop capacities which ensure a high level of resilience and reduce their vulnerability towards climate change. Mainstreaming climate change and energy-related topics into school curricula from geography and biology over ethics to physics and chemistry is long overdue and should be

Barbara Hinger (Hg.), Zweite „Tagung der Fachdidaktik“ 2015.

Sprachsensibler Sach-Fach-Unterricht - Sprachen im Sprachunterricht.

(C) 2016 innsbruck university press, ISBN 978-3-903122-51-2, DOI 10.15203/3122-51-2 
urgently intensified. Education for Sustainable Development (ESD) provides a well-acknowledged framework for this purpose. In the sense of lifelong learning, this also applies to teacher education and training in particular, but can be expanded to other academic and vocational educations as well.

\section{References}

Allison, I., Bindoff, N. L., Bindoff, R. A., Bindschadler, R. A., Cox, P. M., de Noblet, N., England, M. H., Francis, J. E., Gruber, N., Haywood, A. M., Karoly, D. J., Kaser, G., Le Quéré, C., Lenton, T. M., Mann, M. E., McNeil, B. I., Pitman, A. J., Rahmstorf, S., Rignot, E., Schellnhuber, H. J., Schneider, S. H., Sherwood, S. C., Somerville, R. C. J., Steffen, K., Steig, E. J., Visbeck, M. \& Weaver, A. J. (2009). The Copenhagen Diagnosis: Updating the world on the Latest Climate Science. Sydney: The University of New South Wales Climate Change Research Centre.

Angus, S. \& Watson, J. (2009). Does regular online testing enhance student learning in the numerical sciences? Robust evidence from a large data set. British Journal Of Educational Technology, 40 (2), 255-272.

Ballantyne, R., Connell S. \& Fien, J. (1998). Students as Catalysts of Environmental Change: a framework for researching intergenerational influence through environmental education. Environmental Education Research, 4 (3), 285-298.

Bleicher, J. K. (2012). Klimawandel als Apokalypse. Ein Streifzug durch populäre Kinofilme und TV-Movies. In I. Neverla \& M. S. Schäfer (Hrsg.), Das Medien-Klima. Fragen und Befunde der kommunikationswissenschaftlichen Klimaforschung (197-212). Wiesbaden: Verlag für Sozialwissenschaften.

Böhm, M. (2009). Der globale Klimawandel in ausgewäblten österreichischen Geograpbie und Wirtschaftskunde Schulbüchern vor dem Hintergrund der aktuellen Diskussion. Diplomarbeit, Universität Wien. Wien. Available at: http://othes.univie.ac.at/5163/1/2009-06-04_0102184.pdf [29.03.2016].

Corner, A. \& Roberts, O. (2014). Young Voices Report. Available at: http://www.climateoutreach. org.uk/research-reveals-current-climate-engagement-strategies-are-failing-to-reach-youngpeople/ [29.03.2016].

Cosbey, A., Murphy, D. \& Drexhage, J. (2007). Market Mechanisms for Sustainable Development: How do they fit in the various post-2012 climate efforts. The Development Dividend Project, Phase III. Winnipeg: International Institute for Sustainable Development.

Barbara Hinger (Hg.), Zweite „Tagung der Fachdidaktik“ 2015.

Sprachsensibler Sach-Fach-Unterricht - Sprachen im Sprachunterricht.

(C) 2016 innsbruck university press, ISBN 978-3-903122-51-2, DOI 10.15203/3122-51-2 
Darnton, A. (2011). Reference Report: An overview of behaviour change models and their uses. Westminster: University of Westminster, Centre for Sustainable Development. Available at: http://www. peecworks.org/PEEC/PEEC Gen/01796129-001D0211.0/Darnton 2008 Overview of behavior change models and uses.pdf [29.03.2016].

De Hoog, N., Stroebe, W., \& de Wit, J. B. F. (2005). The impact of fear appeals on the processing and acceptance of action recommendations. Personality and Social Psychology Bulletin, 31, (1), $24-33$.

Demirel, Ö. (2005). Program Development in Education: From Theory to Practice. (8. Auflage). Ankara: Pegem A Publishing house.

Duit, R. (1995). Zur Rolle der konstruktivistischen Sichtweise in der natur-wissenschaftsdidaktischen Lehr-Lernforschung. Zeitschrift für Pädagogik, 41 (6), 905-926.

Dunlop, J. C. \& Grabinger, R. S. (1996). Rich Environments for the Active Learning in Higher Education. In G. B. Wilson (Ed.), Constructing Learning Environments: Case Studies in Instructional Design. Englewood Cliffs, NJ: Educational Technology Publications.

Ereaut, G., \& Segnit, N. (2006). Warm words: How are we telling the climate story and can we tell it better? London: Institute for Public Policy Research.

Gruber, L. (2015). Qualitative Evaluierung des Projekts ActAdapt. Auswirkungen spezifischer Veranstaltungen verschiedener Phasen des Projekts auf das Energiebewusstsein bei Jugendlichen. Diplomarbeit, Universität Innsbruck. Innsbruck.

Hegerl, G., Zwiers, F., Bracannot, P., Gillett, N., Luo, Y. \& Marengo Orsini, J. (2007): Unterstanding and Attributing Climate Change. In: Solomon, S., Quin, D., Manning, M., Chen, Z., Marquis, M. \& Averyt, K. (Eds.): Climate Change 2007. The Physical Science Basis. Contribution of Working Group I to the Fourth Assessment Report of the Intergovernmental Panel of Climate Change. Cambridge: Cambridge UP.

Hiramatsu, A., Kurisu, K., Nakamura, H., Teraki, S. \& Hanaki, K. (2014). Spillover Effect on Families Derived from Environmental Education for Children. Low Carbon Economy, 5, 40-50.

Hines, J., Hungerford, H. \& Tomera, A. (1987). Analysis and synthesis of research on responsible environmental behavior. A meta-analysis. Journal of Environmental Education, 18 (2), 1-8.

Hulme, M. (2009). Why we disagree about climate change: understanding controversy, inaction, and opportunity. New York: Cambridge University Press.

IPCC, 2013: Summary for Policymakers. In: Stocker, T.F., D. Qin, G.-K. Plattner, M. Tignor, S.K. Allen, J. Boschung, A. Nauels, Y. Xia, V. Bex and P.M. Midgley (Eds.) Climate Change 2013: The Physical Science Basis. Contribution of Working Group I to the Fifth Assessment Report of the Intergovern-

Barbara Hinger (Hg.), Zweite „Tagung der Fachdidaktik“ 2015.

Sprachsensibler Sach-Fach-Unterricht - Sprachen im Sprachunterricht.

(C) 2016 innsbruck university press, ISBN 978-3-903122-51-2, DOI 10.15203/3122-51-2 
mental Panel on Climate Change. Cambridge University Press, Cambridge, United Kingdom and New York, NY, USA.

Jackson, T. (2005). Motivating Sustainable Consumption: A Review of Evidence On Consumer Behaviour And Behavioural Change. A report to the Sustainable Development Research Network. London: The Sustainable Development Research Network.

Kattmann, U. (2003). Vom Blatt zum Planeten - Scientific Literacy und kumulatives Lernen im Biologieunterricht und darüber hinaus. In B. Moschner, H. Kiper \& U. Kattmann (Hrsg.), PIS A 2000 als Herausforderung. Hohengehren, Baltmannsweiler: Schneider.

Kloor, K. (2011). The debate over climate communications heat up. Yale Climate Connections. Available at: http://www.yaleclimateconnections.org/2011/12/the-debate-over-climate-communication-heats-up/ [29.03.2016].

Lowe, T., Brown, K., Dessai, S., de Franca Doria, M., Haynes, K. \& Vincent, K. (2006). Does tomorrow ever come? Disaster narrative and public perceptions of climate change. Public Understanding of Science, 15, 435-457.

Mandl, H. (2006). Wissensaufbau aktiv gestalten. In G. Becker, I. Behnken, H. Gropengießer, N. Neuß (Hrsg.), Lernen (28-30). Seelze: Friedrich.

Maio, G. B., Verplanken, B., Manstead, A. S. R., Stroebe, W., Abraham, C., Sheeran, P. \& Conner, M. (2007). Social Psychological Factors in Lifestyle Change and Their Relevance to Policy. Journal of Social Issues and Policy Review, 1 (1), 99-137.

Matthews, P. H. (2002). The Concise Oxford Dictionary of Linguistics. Oxford: Oxford University Press.

McCutcheon, L. F. (1981). Infuences of energy conservation education no attitudes and behaviors of selected youths in Piedmont, North Carolina. Dissertation, University of North Carolina at Greensboro. Greensboro.

Mitchell, M. (1993). Situational Interest: Its Multifaceted Structure in the Secondary School Mathematics Classroom. Journal of Educational Psychology. 85(3), 424-436.

Moser, S. (2009). Communicating climate change: history, challenges, process and future directions. Wiley Interdisciplinary Reviews: Climate Change, 1 (1), 31-53.

Nisbet, M. C. \& Mooney, C. (2007). Framing science. Science, 316, 56.

Ockwell, D., Whitmarsh, L. \& O’Neill, S. (2009). Reorienting Climate Change Communication for Effective Mitigation: Forcing People to be Green or Fostering Grass-Roots Engagement? Science Communication, 30 (3), 305-327. Available at: http://dx.doi.org/10.1177/1075547008328969 [29.03.2016].

Barbara Hinger (Hg.), Zweite „Tagung der Fachdidaktik“ 2015.

Sprachsensibler Sach-Fach-Unterricht - Sprachen im Sprachunterricht.

(C) 2016 innsbruck university press, ISBN 978-3-903122-51-2, DOI 10.15203/3122-51-2 
O`Neill, S. \& Nicholson-Cole, S. (2009). „Fear Won't Do It“: Promoting Positive Engagement With Climate Change Through Visual and Iconic Representations. Science Communication, 30 (3), 355-379.

Partian, J. D. (1979). An Assessment of energy cognizance, attitude toward energy conservation, and perceived energy conservation behaviour of selected public school educators. Dissertation, Texas A\&M University Pintrich. Pintrich.

Pintrich, P. R., Marx, R. W., Boyle, R. A. (1993). Beyond cold conceptual change: The role of motivational beliefs and classroom contextual factors in the process of conceptual change. Review of Educational Research, 63, 167-199.

Posner, G. J., Strike, K. A., Hewson, P. W. \& Gertzog, W. A. (1982). Accommodation of a scientific conception: Toward a theory of conceptual change. Science Education, 66, 211-227.

Riede, M.; Link, S.; Keller, L.; Schneitter, E. (2014): Forschungs-Bildungs-Kooperationen als Schlüssel zu erfolgreicher Bewusstseinsbildung in den Bereichen Erneuerbare Energien, Energieeffizienz, Klimaschutz und Klimawandelanpassung. In: Bachhiesl, U.: 13. Symposium Energieinnovation. Innehalten und Ausblick: Effektivität und Effizienz für die Energiewende. Graz: Verlag der Technischen Universität Graz.

Riemeier, T. (2007). Moderater Konstruktivismus. In D. Krüger \& H. Vogt (Hrsg.), Theorien in der biologiedidaktischen Forscbung. Berlin: Springer.

Scriven, M. (1991). Evaluation thesaurus. Newbury Park: Sage Publications.

Solomon, S., Qin, D., Manning, M., Chen, Z., Marquis, M. \& Averyt, K. (2007): Climate Change 2007. The Physical Science Basis. Contribution of Working Group I to the Fourth Assessment Report of the Intergovernmental Panel Climate Change. Cambridge: Cambridge UP.

Spence, A. \& Pidgeon, N. F. (2009). Psychology, climate change and sustainable behaviour. Environment, 51, 8-18.

Spence, A. \& Pidgeon, N. F. (2010). Framing and communicating climate change: The effects of distance and outcome frame manipulations. Global Environmental Change, 20, 656-667.

Sprinz, D. (2010). Die „Sandwichlösung“ für die globale Klimapolitik. In Ch. Ehrhart (Hrsg.), Delivering Tomorrow - Zukunftstrend Nachbaltige Logistik (71-74). Bonn: Deutsche Post AG.

Svanström, M., Lozano-Garzia, F. J. \& Rowe, D. (2008). Learning outcomes for sustainable development in higher education. International Journal of Sustainability in Higher Education, 9, 339-351.

Sweney, M. (2009). Government Climate Change Ad Investigated After 350 Complaints. The Guardian. Available at: http://www.guardian.co.uk/media/2009/oct/21/climate-changeadvertising-standards [29.03.2016].

Barbara Hinger (Hg.), Zweite „Tagung der Fachdidaktik“ 2015.

Sprachsensibler Sach-Fach-Unterricht - Sprachen im Sprachunterricht.

(C) 2016 innsbruck university press, ISBN 978-3-903122-51-2, DOI 10.15203/3122-51-2 
Thaler, R. H. \& Sunstein, C. R. (2008). Nudge: Improving Decisions about Health, Wealth and Happiness. New Haven: Yale University Press.

Voelkel, S. (2013). Combining the formative with the summative: the development of a two-stage online test to encourage engagement and provide personal feedback in large classes. Research In Learning Technology, 21. Available at: http://www.researchinlearningtechnology.net/index.php/ rlt/article/viewFile/19153/pdf 1 [29.03.2016].

Vogt, H. (2007). Theorie des Interesses und des Nicht-Interesses. In D. Krüger \& H. Vogt (Hrsg.), Theorien in der biologiedidaktischen Forschung (9-20). Berlin: Springer.

Witte, K. (1994). Fear control and danger control: A test of the extended parallel process model (EPPM). Communication Monographs, 61 (2), 113-134.

Wolf, J. \& Moser, S. (2011). Individual understandings, perceptions, and engagement with climate change: insights from in-depth studies across the world. Wiley Interdisciplinary Reviews: Climate Change, 2 (4), 547-569.

Zsóka, A., Szerényi, Z. M., Széchy, A. \& Kocsis, T. (2013). Greening due to environmental education? Environmental knowledge, attitudes, consumer behavior and everyday pro-environmental activities of Hungarian high school and university students. Journal of Cleaner Production, 48, 126-138. 
